Article

\title{
Vitamin D Deficiency in Cushing's Disease: Before and After Its Supplementation
}

\author{
Valentina Guarnotta ${ }^{1}$, Francesca Di Gaudio ${ }^{2}$ and Carla Giordano ${ }^{1, * \text { (D) }}$ \\ 1 Department of Health Promotion, Maternal-Infantile Care, Excellence Internal and \\ Specialist Medicine "G. D'Alessandro" [PROMISE], Section of Endocrine Disease and Nutrition, \\ University of Palermo, 90127 Palermo, Italy; valentina.guarnotta@unipa.it \\ 2 Biochemistry Head CQRC Division (Quality Control and Biochemical Risk), \\ Department of Health Promotion, Maternal-Infantile Care, Excellence Internal and \\ Specialist Medicine "G. D'Alessandro" [PROMISE], University of Palermo, 90127 Palermo, Italy; \\ francesca.digaudio@unipa.it \\ * Correspondence: carla.giordano@unipa.it; Tel.: +39-0916552110; Fax: +39-0916552123
}

Citation: Guarnotta, V.; Di Gaudio, F.; Giordano, C. Vitamin D Deficiency in Cushing's Disease: Before and After Its Supplementation. Nutrients 2022, 14, 973. https://doi.org/10.3390/ nu14050973

Academic Editor: Edgard Delvin

Received: 31 January 2022

Accepted: 23 February 2022

Published: 25 February 2022

Publisher's Note: MDPI stays neutral with regard to jurisdictional claims in published maps and institutional affiliations.

Copyright: (C) 2022 by the authors. Licensee MDPI, Basel, Switzerland. This article is an open access article distributed under the terms and conditions of the Creative Commons Attribution (CC BY) license (https:// creativecommons.org/licenses/by/ $4.0 /)$.

\begin{abstract}
Background: The primary objective of the study was to assess serum 25-hydroxyvitamin $\mathrm{D}[25(\mathrm{OH}) \mathrm{D}]$ values in patients with Cushing's disease (CD), compared to controls. The secondary objective was to assess the response to a load of 150,000 U of cholecalciferol. Methods: In 50 patients with active $\mathrm{CD}$ and 48 controls, we evaluated the anthropometric and biochemical parameters, including insulin sensitivity estimation by the homeostatic model of insulin resistance, Matsuda Index and oral disposition index at baseline and in patients with CD also after 6 weeks of cholecalciferol supplementation. Results: At baseline, patients with CD showed a higher frequency of hypovitaminosis deficiency $(p=0.001)$ and lower serum $25(\mathrm{OH}) \mathrm{D}(p<0.001)$ than the controls. Six weeks after cholecalciferol treatment, patients with CD had increased serum calcium $(p=0.017), 25(\mathrm{OH}) \mathrm{D}$ $(p<0.001)$, ISI-Matsuda $(p=0.035)$, oral disposition index $(p=0.045)$ and decreased serum PTH $(p=0.004)$ and total cholesterol $(p=0.017)$ values than at baseline. Multivariate analysis showed that mean urinary free cortisol (mUFC) was independently negatively correlated with serum $25(\mathrm{OH}) \mathrm{D}$ in CD. Conclusions: Serum 25(OH)D levels are lower in patients with CD compared to the controls. Vitamin D deficiency is correlated with mUFC and values of mUFC $>240 \mathrm{nmol} / 24 \mathrm{~h}$ are associated with hypovitaminosis D. Cholecalciferol supplementation had a positive impact on insulin sensitivity and lipids.
\end{abstract}

Keywords: glucocorticoid; hypercortisolism; 25-hydroxyvitamin D; cholecalciferol

\section{Introduction}

Vitamin D is the precursor of a hormone with pleiotropic effects. Its deficiency has been largely investigated and shown to be associated with many complications including diabetes mellitus, adrenal insufficiency, cardiovascular disease, neurological disorders and other endocrinopathies [1-3].

Vitamin D, also known as cholecalciferol, is first formed in the skin by the photolysis of 7-dehydrocholesterol and after hydroxylated in the liver to 25-hydroxyvitamin D [25(OH)D]. It is further transformed in the kidney into 1,25-dihydroxyvitamin D3 (1,25(OH)2D3) (calcitriol) that is the active form [4].

Cushing's disease (CD) is characterized by a cortisol excess due to autonomous pituitary ACTH secretion. Patients with CD show many comorbidities such as cardiovascular disease, metabolic disease, diabetes mellitus, metabolic syndrome, dyslipidemia, obesity, osteoporosis/osteopenia and infections that contribute to increasing the mortality risk for these patients [5-11]. Indeed, GCs are key regulators of intermediary metabolism promoting hepatic gluconeogenesis and glycogenosis and on lipid metabolism favouring 
the deposition of fat to the upper trunk and the face [12]. They stimulate water diuresis, glomerular filtration rate and renal plasma flow and these effects result in arterial hypertension and atherosclerosis. GCs reduce bone remodelling, augment urinary calcium excretion and decrease the intestinal calcium absorption. In addition, they act on immune and hematological systems inhibiting the secretion of interleukins and increasing the red blood cell count, respectively [12].

An interesting relationship exists between glucocorticoids (GCs) and vitamin D values [13-16]. Indeed, exogenous steroid therapy has been reported to be associated with vitamin deficiency [13]. The mechanism by which GCs reduce $25(\mathrm{OH}) \mathrm{D}$ levels is not direct, but indirect, regulating vitamin D receptor expression in many tissues and cells [17,18]. Some authors have shown that treatment with dexamethasone in mice was associated with a decrease in $1 \alpha$-hydroxylase which is involved in the conversion from $25(\mathrm{OH}) \mathrm{D} 3$ to the active metabolite 1,25(OH)2D3 and an increase in 24-hydroxylase, able to break down the active form of calcitriol, in inactive, reducing circulating $25(\mathrm{OH}) \mathrm{D}$ levels [19]. In a clinical setting, controversial data have been reported on GCs effects on serum 1,25(OH)2D concentrations [20-23]. A likely reason for these discrepancies might be the marked heterogeneity of the studied groups. Some of these studies were performed in humans [23-26], and others in animal models $[27,28]$, but only a few studies were conducted in subjects with endogenous hypercortisolism.

Low serum 25(OH)D levels have significant skeletal and extra-skeletal consequences such as myopathy, high risk of fractures and also affect the immune system and metabolism. All of these systems are impaired in patients with hypercortisolism and a vitamin D deficiency may provide a further aggravation of CD comorbidities. Indeed, it may cause a reduced intestinal calcium absorption resulting in secondary hypocalcemia and hyperparathyroidism leading to a bone demineralization. Its deficiency can contribute to obesity and metabolic syndrome due to the lack of antiadipogenic effect of vitamin D and to cardiovascular disease by a deregulation of the renin-angiotensin-aldosterone system, cardiac contractility and increase in cytokine release [29]. In the end, vitamin D deficiency causes impaired insulin sensitivity and immune system [30].

The discrepancies that emerge in the above-mentioned studies suggest a need to investigate the role of $25(\mathrm{OH}) \mathrm{D}$ in patients with $\mathrm{CD}$. Therefore, the primary objective of the study was to evaluate serum $25(\mathrm{OH}) \mathrm{D}$ levels in patients with $\mathrm{CD}$, compared to a control group matched for age, BMI and gender, and search for a possible correlation with the degree of hypercortisolism. The secondary objective was to evaluate the response to a course of 150,000 U of cholecalciferol on metabolic and hormonal parameters 6 weeks after the administration in patients with CD.

\section{Materials and Methods}

\subsection{Subjects and Study Design}

Fifty patients with active CD, 43 of them women (86\%) and 7 of them men $(20 \%)$ (mean age $50.9 \pm 17.4$ years; mean duration of disease $32.5 \pm 22.4$ years), followed from January 2016 to December 2020, by the Endocrinology of the University of Palermo, were included in the current study. Clinical practice guidelines and a recent consensus statement were used to diagnose CD [31,32].

We recruited a control group matched for age, BMI and gender in the same temporal period. It was composed of 48 patients, 33 women $(82.5 \%$ ) and 7 men $(17.5 \%)$ (mean age $48.5 \pm 13.4$ years) were evaluated by our team for a suspicion not biochemically confirmed of Cushing's syndrome (CS).

In all patients, we evaluated phenotypic characteristics including moon face, facial rubor, dorsal fat pad or buffalo hump, defined as a fatty tissue deposit between the shoulders, purple striae, defined as wide, reddish-purple streaks, and myopathy defined as muscle weakness at the proximal level.

We also assessed cardiovascular, metabolic and bone comorbidities. The diagnosis of metabolic syndrome was based on National Cholesterol Education Program Adult 
Treatment Panel (NCEP ATP III) criteria, while the diagnosis of diabetes mellitus and prediabetes were based on the American Diabetes Association (ADA, Arlington, VA, USA) criteria $[33,34]$.

Among patients with diabetes mellitus (18 out of 50), 16 were treated with metformin alone, while 2 were treated with a combination of metformin and GLP-1 agonist receptors. Metformin and GLP-1 agonist receptors were discontinued $24 \mathrm{~h}$ and 2 weeks before metabolic evaluations, respectively, to avoid any interference with metabolic parameters. Diabetic patients were on good metabolic control $(\mathrm{HbA} 1 \mathrm{c} \leq 7 \%)$. Both $\mathrm{CD}$ patients and the controls were naïve to cholecalciferol.

In $\mathrm{CD}$ and the controls, BMI and waist circumference (WC), fasting serum lipids (total cholesterol (TC), HDL cholesterol, LDL cholesterol and triglycerides (TG), HbA1c, glycaemia, insulinaemia, albumin corrected calcium, phosphorus and parathyroid hormone (PTH) were assessed. To avoid seasonal influences, serum 25(OH)D levels were only assayed between winter and spring seasons (November-April). We evaluated urinary free cortisol (UFC) as the mean of three $24 \mathrm{~h}$ urine collections (mUFC), cortisol after a low dose of dexamethasone suppression test and plasma ACTH. We defined patients with mild hypercortisolism when mUFC levels not exceeding twice the upper limit of normal (ULN), moderate hypercortisolism by a level of mUFC more than 2 to 5 times the ULN and severe hypercortisolism by a mUFC level more than 5 times the ULN, as previously reported [35].

As defined by the Endocrine Society guidelines, we considered $25(\mathrm{OH}) \mathrm{D}$ deficiency for values $<20 \mathrm{ng} / \mathrm{mL}(50 \mathrm{nmol} / \mathrm{L})$, insufficiency as levels of 20-30 ng/mL (50-75 nmol/L) and sufficiency for values $\geq 30 \mathrm{ng} / \mathrm{mL}$ ( $\geq 75 \mathrm{nmol} / \mathrm{L})$ [36]. In addition, severe 25(OH)D deficiency was defined by levels $<10 \mathrm{ng} / \mathrm{mL}(<25 \mathrm{nmol} / \mathrm{L})$ [37].

As markers of insulin sensitivity, we calculated the homeostatic model of insulin resistance (HOMA2-IR) [38], and in 32 patients with CD and in 40 controls who had no previous diagnosis of diabetes, we also evaluated the Matsuda index of insulin sensitivity (ISI-Matsuda) [39], the oral disposition index (DIo) [40] and the area under the curve for insulin (AUC2h insulinemia) and glucose (AUC2h glycaemia).

At the baseline visit, we assessed patients' lifestyle habits: physical activity level, balanced diet (consumption of dairy products, meat, coffee, soft drinks), exposure to ultraviolet (UV) radiation, smoking status and alcohol use.

We excluded patients with adrenal-dependent hypercortisolism, pregnancy, taking oral contraceptives, liver or renal disease, cholecalciferol supplementation within 3 months before the study, malabsorption syndrome and exposure to ultraviolet (UV) radiation (solarium and sunscreen usage).

Patients with CD received an oral load dose of cholecalciferol of 150,000 UI [41,42] and biochemical parameters (metabolic and hormonal) were assayed 6 weeks after administration.

The study protocol was approved by the Ethics Committee of the Policlinico Paolo Giaccone hospital. All patients signed a written informed consent.

\subsection{Assays}

Biochemical parameters were measured by standard methods (Modular P800, Roche, Milan, Italy), as previously reported [9].

Hormonal parameters were measured by electrochemiluminescence immunoassay (ECLIA, Elecsys, Roche, Milan, Italy) following the manufacturer's instructions, as previously reported [9].

Mean UFC was measured by mass spectrometry, as previously reported [35].

Normal values for hormonal markers were defined as follows: ACTH 2.2-14 pmol/L and UFC 59-378 nmol/24 h.

\subsection{Statistical Analysis}

We used statistical Packages for Social Science SPSS version 19 (SPSS, Inc., Chicago, IL, USA) for data analysis. The normality of quantitative variables was tested with the ShapiroWilk test. We calculated mean \pm SD for continuous variables and rates and proportions 
for categorical variables. The differences between paired continuous variables (CD vs. controls) were analysed using one-way ANOVA. We used univariate Pearson correlation to evaluate the relations with the outcome parameters. For those variables which were significant at univariate correlation, we performed multiple linear regression analysis to identify independent predictors of the dependent variable 25(OH)D. A $p$-value of 0.05 was considered statistically significant. A receiver operating characteristic (ROC) analysis was performed to investigate the diagnostic ability of significantly associated risk factors to predict $25(\mathrm{OH}) \mathrm{D}$ deficiency. The ROC curve is plotted as sensitivity versus 1-specificity. The area under the ROC curve (AUC) was estimated to measure the overall performance of the predictive factors for serum $25(\mathrm{OH}) \mathrm{D}$ deficiency.

\section{Results}

At baseline, patients with CD had a higher frequency of arterial hypertension $(p=0.009)$, osteoporosis/osteopenia $(p=0.002)$, hypercholesterolemia $(p=0.002)$, diabetes mellitus $(p=0.026)$, myopathy $(p<0.001)$, facial rubor $(p=0.005)$, buffalo hump $(p=0.002)$ and hypovitaminosis deficiency $(p=0.001)$ than the controls (Table 1$)$.

Table 1. Comorbidities of patients with $\mathrm{CD}$ and controls at baseline.

\begin{tabular}{|c|c|c|c|}
\hline & Controls & Cushing's Disease & \multirow{3}{*}{$p$} \\
\hline & $($ No. $=48)$ & $($ No. $=50)$ & \\
\hline & Subjects (\%) & Subjects (\%) & \\
\hline \multicolumn{4}{|l|}{ Gender } \\
\hline Male & $9(18.7 \%)$ & $7(14 \%)$ & \multirow[t]{2}{*}{0.475} \\
\hline Female & $39(81.3 \%)$ & $43(86 \%)$ & \\
\hline Arterial hypertension & $18(37.5 \%)$ & $32(64 \%)$ & 0.009 \\
\hline Osteoporosis/osteopenia & $7(14.6 \%)$ & $21(42 \%)$ & 0.002 \\
\hline Visceral obesity & $38(79.1 \%)$ & $44(88 \%)$ & 0.224 \\
\hline Metabolic syndrome & $19(39.6 \%)$ & $29(58 \%)$ & 0.069 \\
\hline Hypercholesterolemia & $14(29.1 \%)$ & $30(60 \%)$ & 0.002 \\
\hline Hypertriglyceridemia & $11(22.9 \%)$ & $13(26 \%)$ & 0.486 \\
\hline Low HDL & $14(29.1 \%)$ & $19(38 \%)$ & 0.361 \\
\hline Cardiovascular disease & 0 & $5(10 \%)$ & 0.118 \\
\hline Peripheral vascular disease & 0 & $1(2 \%)$ & 0.489 \\
\hline Diabetes mellitus & $6(12.5 \%)$ & $24(48 \%)$ & 0.026 \\
\hline IFG & 0 & $6(12 \%)$ & 0.622 \\
\hline IGT & $6(12.5 \%)$ & $7(14 \%)$ & 0.678 \\
\hline IFG + IGT & $1(2 \%)$ & $3(6 \%)$ & 0.457 \\
\hline Moon face & $24(50 \%)$ & $33(66 \%)$ & 0.108 \\
\hline Myopathy & $12(25 \%)$ & $36(72 \%)$ & $<0.001$ \\
\hline Facial rubor & $9(18.7 \%)$ & $23(46 \%)$ & 0.005 \\
\hline Buffalo hump & $17(35.4 \%)$ & $33(66 \%)$ & 0.002 \\
\hline Purple striae & $11(22.9 \%)$ & $15(30 \%)$ & 0.245 \\
\hline \multicolumn{4}{|l|}{ Hypovitaminosis D } \\
\hline Deficiency & $4(8.4 \%)$ & $26(52 \%)$ & 0.001 \\
\hline Insufficiency & $10(20.8 \%)$ & $14(28 \%)$ & 0.545 \\
\hline Sufficiency & $34(70.8 \%)$ & $10(20 \%)$ & 0.004 \\
\hline
\end{tabular}

By contrast, the controls had a higher frequency of vitamin D sufficiency $(p=0.004)$. Patients with CD also had higher WC $(p=0.031)$, PTH $(p=0.003)$, glycaemia $(p=0.010)$, $\operatorname{HbA1c}(p=0.004)$, total cholesterol $(p<0.001)$, LDL cholesterol $(p=0.002)$, ACTH $(p<0.001)$, mUFC ( $p=0.001)$, cortisol after a low dose of dexamethasone suppression test $(p=0.001)$ and lower $25(\mathrm{OH}) \mathrm{D}(p<0.001)$, ISI-Matsuda $(p=0.007)$ and DIo $(p=0.003)$ than the controls (Table 2). 
Table 2. Anthropometric and biochemical parameters of patients with CD and controls at baseline.

\begin{tabular}{|c|c|c|c|}
\hline & $\begin{array}{l}\text { Controls Baseline } \\
(\text { No. }=48)\end{array}$ & $\begin{array}{c}\text { Cushing's Disease Baseline } \\
(\text { No. }=50)\end{array}$ & \multirow[t]{2}{*}{$p$} \\
\hline & Mean \pm SD & Mean \pm SD & \\
\hline Age (yrs) & $48.2 \pm 13.4$ & $50.9 \pm 17.4$ & 0.815 \\
\hline \multicolumn{4}{|l|}{ Anthropometric parameters } \\
\hline BMI $\left(\mathrm{kg} / \mathrm{m}^{2}\right)$ & $31.9 \pm 5.01$ & $33.1 \pm 6.41$ & 0.321 \\
\hline Waist circumference $(\mathrm{cm})$ & $105.4 \pm 12.7$ & $110.7 \pm 8.97$ & 0.031 \\
\hline \multicolumn{4}{|l|}{ Metabolic parameters } \\
\hline Creatinine $(\mathrm{mg} / \mathrm{dL})$ & $0.78 \pm 0.25$ & $0.81 \pm 0.31$ & 0.601 \\
\hline Calcium (mg/dL) & $9.43 \pm 0.46$ & $9.46 \pm 0.61$ & 0.841 \\
\hline Phosphorus (mg/dL) & $3.83 \pm 0.67$ & $3.46 \pm 0.54$ & 0.125 \\
\hline Parathyroid hormone $(\mathrm{pg} / \mathrm{mL})$ & $33.8 \pm 8.03$ & $54.1 \pm 22.7$ & 0.003 \\
\hline $25(\mathrm{OH}) \mathrm{D}(\mathrm{ng} / \mathrm{mL})$ & $28.7 \pm 8.49$ & $16.7 \pm 8.18$ & $<0.001$ \\
\hline Glycaemia (mmol/L) & $4.97 \pm 2.77$ & $6.66 \pm 2.19$ & 0.010 \\
\hline $\mathrm{HbA} 1 \mathrm{c}(\%)$ & $5.79 \pm 0.73$ & $6.73 \pm 1.09$ & 0.004 \\
\hline Total cholesterol (mmol/L) & $4.51 \pm 0.82$ & $5.34 \pm 1.07$ & $<0.001$ \\
\hline HDL cholesterol (mmol/L) & $1.15 \pm 0.29$ & $1.19 \pm 0.45$ & 0.184 \\
\hline Triglycerides $(\mathrm{mmol} / \mathrm{L})$ & $1.66 \pm 0.43$ & $1.73 \pm 0.67$ & 0.585 \\
\hline LDL cholesterol (mmol/L) & $2.62 \pm 0.91$ & $3.31 \pm 0.99$ & 0.002 \\
\hline HOMA-IR & $3.07 \pm 1.01$ & $4.67 \pm 2.83$ & 0.051 \\
\hline ISI-Matsuda & $4.14 \pm 1.59$ & $3.02 \pm 2.18$ & 0.007 \\
\hline Oral disposition index & $3.75 \pm 0.54$ & $2.25 \pm 2.04$ & 0.003 \\
\hline \multicolumn{4}{|l|}{ Hormonal parameters } \\
\hline $\mathrm{ACTH}(\mathrm{pmol} / \mathrm{L})$ & $7.72 \pm 2.19$ & $15.1 \pm 6.56$ & $<0.001$ \\
\hline Mean urinary free cortisol (nmol/24 h) & $310.2 \pm 104.1$ & $604.7 \pm 65.6$ & 0.001 \\
\hline $\begin{array}{l}\text { Cortisol after low dose of dexamethasone } \\
\text { suppression test (nmol/L) }\end{array}$ & $44.4 \pm 11.5$ & $361.4 \pm 98.4$ & 0.001 \\
\hline
\end{tabular}

Six weeks after cholecalciferol treatment, patients with CD showed increased serum calcium $(p=0.017), 25(\mathrm{OH}) \mathrm{D}(p<0.001)$, ISI-Matsuda $(p=0.035)$, DIo $(p=0.045)$ and a decrease in PTH $(p=0.004)$ and total cholesterol $(p=0.017)$ levels than at baseline (Table 3$)$.

Table 3. Anthropometric and biochemical parameters at baseline and 6 weeks after cholecalciferol supplementation in patients with CD.

\begin{tabular}{|c|c|c|c|}
\hline & \multicolumn{2}{|c|}{$\begin{array}{l}\text { Cushing's Disease } \\
(\text { No. }=50)\end{array}$} & \multirow{3}{*}{$p$} \\
\hline & Baseline & Six Weeks After Cholecalciferol & \\
\hline & Mean \pm SD & Mean \pm SD & \\
\hline \multicolumn{4}{|l|}{ Anthropometric parameters } \\
\hline BMI $\left(\mathrm{kg} / \mathrm{m}^{2}\right)$ & $33.1 \pm 6.41$ & $32.9 \pm 7.43$ & 0.880 \\
\hline Waist circumference $(\mathrm{cm})$ & $110.7 \pm 8.97$ & $109.8 \pm 7.08$ & 0.586 \\
\hline \multicolumn{4}{|l|}{ Metabolic parameters } \\
\hline Creatinine $(\mathrm{mg} / \mathrm{dL})$ & $0.81 \pm 0.32$ & $0.78 \pm 0.26$ & 0.615 \\
\hline Calcium (mg/dL) & $9.46 \pm 0.61$ & $9.75 \pm 0.56$ & 0.017 \\
\hline Phosphorus (mg/dL) & $3.46 \pm 0.54$ & $3.54 \pm 0.43$ & 0.424 \\
\hline Parathyroid hormone (pg/mL) & $54.1 \pm 22.7$ & $40.5 \pm 11.5$ & 0.004 \\
\hline $25(\mathrm{OH}) \mathrm{D}(\mathrm{ng} / \mathrm{mL})$ & $16.7 \pm 8.18$ & $30.7 \pm 9.65$ & $<0.001$ \\
\hline Glycaemia (mmol/L) & $6.66 \pm 2.19$ & $6.02 \pm 1.65$ & 0.109 \\
\hline Total cholesterol (mmol/L) & $5.34 \pm 1.07$ & $4.87 \pm 0.81$ & 0.017 \\
\hline HDL cholesterol (mmol/L) & $1.19 \pm 0.45$ & $1.21 \pm 0.38$ & 0.465 \\
\hline Triglycerides $(\mathrm{mmol} / \mathrm{L})$ & $1.73 \pm 0.67$ & $1.68 \pm 0.41$ & 0.660 \\
\hline LDL cholesterol (mmol/L) & $3.31 \pm 0.99$ & $2.98 \pm 0.75$ & 0.068 \\
\hline
\end{tabular}


Table 3. Cont.

\begin{tabular}{|c|c|c|c|}
\hline & \multicolumn{2}{|c|}{$\begin{array}{c}\text { Cushing's Disease } \\
(\text { No. }=50)\end{array}$} & \multirow{3}{*}{$p$} \\
\hline & Baseline & Six Weeks After Cholecalciferol & \\
\hline & Mean \pm SD & Mean \pm SD & \\
\hline HOMA-IR & $4.67 \pm 2.83$ & $3.97 \pm 2.02$ & 0.166 \\
\hline ISI-Matsuda & $3.02 \pm 2.18$ & $3.76 \pm 1.12$ & 0.035 \\
\hline Oral disposition index & $2.25 \pm 2.04$ & $2.97 \pm 1.89$ & 0.045 \\
\hline \multicolumn{4}{|l|}{ Hormonal parameters } \\
\hline $\mathrm{ACTH}(\mathrm{pmol} / \mathrm{L})$ & $15.1 \pm 6.56$ & $14.3 \pm 6.36$ & 0.519 \\
\hline Mean urinary free cortisol (nmol/24 h) & $604.7 \pm 65.6$ & $582.5 \pm 54.9$ & 0.075 \\
\hline $\begin{array}{l}\text { Cortisol after low dose of dexamethasone } \\
\text { suppression test ( } \mathrm{nmol} / \mathrm{L})\end{array}$ & $361.4 \pm 98.4$ & $363.9 \pm 89.6$ & 0.895 \\
\hline
\end{tabular}

Considering the degree of hypercortisolism, in patients with severe hypercortisolism we observed $25(\mathrm{OH}) \mathrm{D}$ deficiency in $73.1 \%$ of cases $(53.8 \%$ of them had a severe deficiency) insufficiency in $12.5 \%$ of cases and sufficiency in $6.3 \%$ of cases. In patients with moderate hypercortisolism, we observed $25(\mathrm{OH}) \mathrm{D}$ deficiency in $64.7 \%$ of cases $(29 \%$ of them had a severe deficiency), insufficiency in $23.5 \%$ of cases and sufficiency in $11.8 \%$ of cases. In patients with mild hypercortisolism, we observed deficiency in $52.9 \%$ of cases $(20 \%$ of them had a severe deficiency), insufficiency in $41.1 \%$ of cases and sufficiency in $6 \%$ of cases.

At univariate correlation, in patients with $\mathrm{CD}$ at baseline, serum $25(\mathrm{OH}) \mathrm{D}$ was inversely correlated with glycaemia $(\mathrm{r}=-0.385, p=0.019), \mathrm{HbA1c}(\mathrm{r}=-0.391, p=0.017)$, WC $(\mathrm{r}=-0.373, p=0.023), \operatorname{mUFC}(\mathrm{r}=-0.466, p=0.033)$ and cortisol after a low dose of dexamethasone suppression test $(\mathrm{r}=-0.299, p=0.049)$ (Table 4). In the controls, at baseline, $25(\mathrm{OH}) \mathrm{D}$ was inversely correlated with WC $(\mathrm{r}=-0.130, p=0.042)$ (Table 4$)$.

Table 4. Correlation of serum 25-hydroxyvitamin D [25(OH)D] levels at baseline in patients with Cushing's disease and controls.

\begin{tabular}{ccccc}
\hline & \multicolumn{4}{c}{ 25(OH)D } \\
\cline { 2 - 5 } & \multicolumn{2}{c}{ Cushing's Disease } & \multicolumn{2}{c}{ Controls } \\
\cline { 2 - 5 } & $\mathbf{r}$ & $p$ & $\mathbf{r}$ & $p$ \\
\hline Glycaemia $(\mathrm{mmol} / \mathrm{L})$ & -0.385 & 0.019 & -0.737 & 0.097 \\
HbA1c $(\%)$ & -0.391 & 0.017 & 0.213 & 0.355 \\
BMI $\left(\mathrm{kg} / \mathrm{m}^{2}\right)$ & -0.221 & 0.189 & 0.007 & 0.976 \\
WC $(\mathrm{cm})$ & -0.373 & 0.023 & -0.130 & 0.042 \\
ACTH $(\mathrm{pmol} / \mathrm{L})$ & -0.133 & 0.440 & -0.198 & 0.567 \\
Urinary free cortisol (nmol/24 h) & -0.466 & 0.033 & 0.040 & 0.862 \\
Cortisol after low dose of & & & & \\
dexamethasone suppression test & -0.299 & 0.049 & 0.260 & 0.255 \\
(nmol/L) & & & & \\
\hline
\end{tabular}

Multivariate analysis showed that mUFC was independently inversely associated with $25(\mathrm{OH}) \mathrm{D}(p=0.010)$ in patients with $\mathrm{CD}$ (Figure 1$)$. In the controls, no significant associations were found.

The ROC analysis showed that a cut-off of $\mathrm{mUFC}>240 \mathrm{nmol} / 24 \mathrm{~h}$ was associated with $25(\mathrm{OH}) \mathrm{D}$ deficiency with a specificity of $100 \%$ and a sensitivity of $56.9 \%$, AUC 0.803 (Figure 2). 


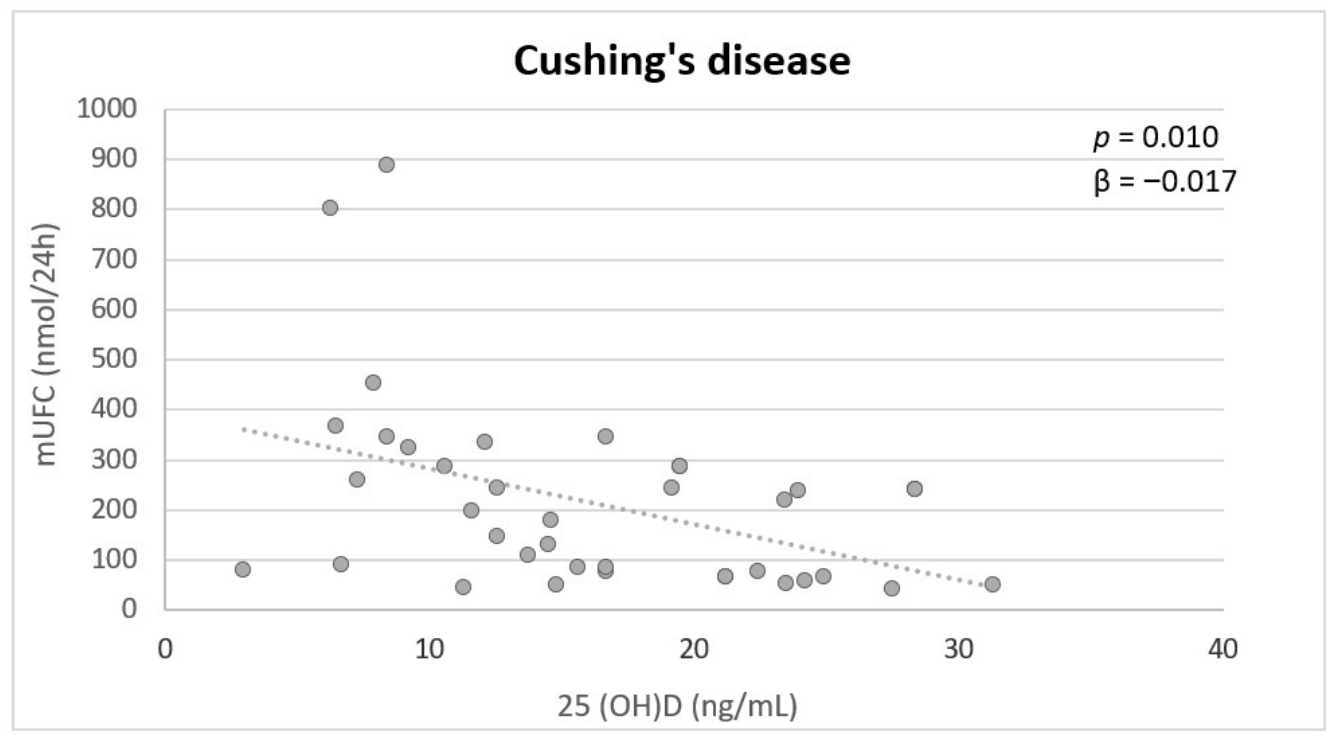

Figure 1. Independent variables associated with serum $25(\mathrm{OH}) \mathrm{D}$ in patients with active $\mathrm{CD}$ at multivariate analysis. mUFC: mean urinary free cortisol.

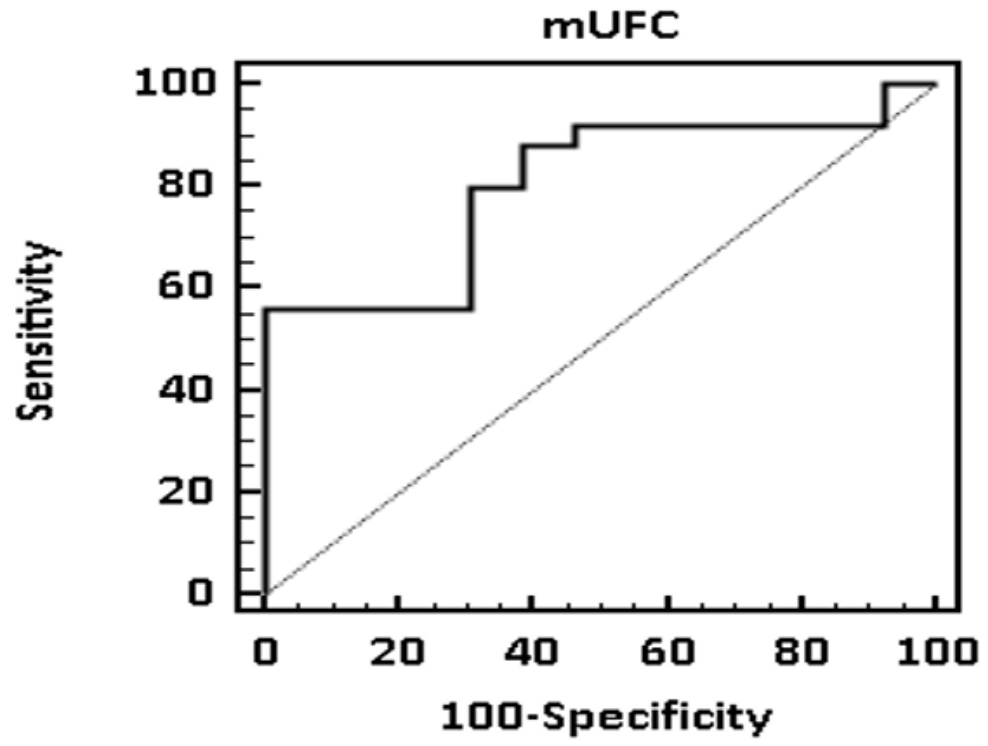

\section{5(OH)D deficiency}

Sensitivity: $56 \%$

Specificity: $100 \%$

Criterion: $>240$

$\mathrm{nmol} / 24 \mathrm{~h}$

AUC: 0.803

$p=0.001$

Figure 2. 25(OH)D status and mUFC. ROC curve showed that a cut-off of mUFC $>240 \mathrm{nmol} / 24 \mathrm{~h}$ could be associated with 25(OH)D deficiency. Statistical analysis was performed using the chi-square test and receiver operator characteristic (ROC) curve analysis.

\section{Discussion}

The present study shows that patients with active CD have lower serum $25(\mathrm{OH}) \mathrm{D}$ values than the controls and that serum 25(OH)D levels are inversely correlated with mUFC in CD. In addition, a cholecalciferol load is associated after 6 weeks from the administration with an improvement of serum $25(\mathrm{OH}) \mathrm{D}$ and glycometabolic and lipid parameters in patients with CD. Furthermore, we found that higher values of mUFC than $240 \mathrm{nmol} / 24 \mathrm{~h}$ are predictive of $25(\mathrm{OH}) \mathrm{D}$ deficiency. The degree of hypercortisolism evaluated by UFC levels is a useful parameter to quantify the "amount" of cortisol secretion, even though it is not sufficiently exhaustive to assess the aggressiveness of the disease [35]. Indeed, a combination of several factors, including the degree of hypercortisolism, but also the duration of the disease, age and other individual predisposing factors, contribute to the aggressiveness of the disease. 
Long-standing studies were conducted on vitamin D levels in patients with CD. Patients with $C D$, with and without osteopenia, were compared before and after oral calcium load showing that serum 1,25 (OH)2D3 plasma levels were higher in subjects with osteopenia than in those without it, likely due to a secondary increase in PTH levels as an effect of hypercortisolism [19]. Another study investigated the effect of hypercortisolism and eucortisolism, showing a reduction in serum 25(OH)D levels, but not in 1,25 $(\mathrm{OH}) 2 \mathrm{D} 3$ in patients with hypercortisolism. By contrast, two other studies found normal serum $25(\mathrm{OH}) \mathrm{D}$ values in patients with $\mathrm{CD}[23,24]$. However, all the above-mentioned studies were conducted on a small sample of patients. Recently, a meta-analysis conducted on the studies that evaluated serum 25(OH)D levels in patients treated with GCs reported lower serum $25(\mathrm{OH}) \mathrm{D}$ levels in these patients compared to healthy subjects [16]. A hypothetical reason was that patients with $\mathrm{CD}$ had low 24-hydroxylase levels than the controls, causing an alteration of vitamin D catabolism.

An interesting in vitro study in NCI-H295R cells found that treatment with 1,25(OH)2D3 decreased corticosterone secretion without affecting cortisol levels [43].

As expected, in the current study, we showed that treatment with cholecalciferol is associated with an improvement in insulin sensitivity and total cholesterol values in patients with CD. Indeed, cholecalciferol supplementation has been reported to be associated with improved peripheral insulin sensitivity and secretion in patients at high risk of diabetes or with type 2 diabetes [44]. A recent meta-analysis on 41 randomized controlled studies showed a significant improvement in total cholesterol levels after cholecalciferol supplementation. In addition, this improvement was more pronounced in patients with vitamin D deficiency [45,46].

A recent study compared the metabolism of vitamin $\mathrm{D}$ in patients with $\mathrm{CD}$ and controls after cholecalciferol treatment, showing that patients with $\mathrm{CD}$ had a higher $25(\mathrm{OH}) \mathrm{D} / 24,25(\mathrm{OH}) 2 \mathrm{D}$ ratio than healthy controls, likely due to a decrease in 24-hydroxylase activity. The authors concluded that this alteration of vitamin D catabolism might have an influence on the effectiveness of cholecalciferol therapy in CD [47].

There are some limitations in the current study. First, the study is not randomized. Second, the dose of cholecalciferol administered is the same independently of the baseline serum $25(\mathrm{OH}) \mathrm{D}$ values. Third, we did not register the intake of milk and dairy products of the patients included in the study.

In conclusion, serum 25(OH)D levels are lower in subjects with active $\mathrm{CD}$ compared to controls matched for age, BMI and gender. Vitamin D deficiency is correlated with mUFC and values of mUFC $>240 \mathrm{nmol} / 24 \mathrm{~h}$ are predictive of $25(\mathrm{OH}) \mathrm{D}$ deficiency. In addition, cholecalciferol supplementation has a positive impact on insulin sensitivity and lipids and therefore should be considered part of the treatment of patients with CD at diagnosis, in order to improve the comorbidities. However, further studies are needed to evaluate a possible effect of cholecalciferol supplementation on the aggressiveness of CD.

Author Contributions: Conceptualization, V.G. and F.D.G.; methodology, V.G.; software, V.G.; validation, V.G., F.D.G. and C.G.; formal analysis, V.G.; investigation, V.G.; resources, F.D.G.; data curation, V.G.; writing - original draft preparation, V.G.; writing - review and editing, V.G.; visualization, V.G.; supervision, C.G.; project administration, C.G.; funding acquisition, C.G. All authors have read and agreed to the published version of the manuscript.

Funding: This research received no external funding.

Institutional Review Board Statement: The study was conducted in accordance with the Declaration of Helsinki, and was approved by the Institutional Review Board (or Ethics Committee) of Policlinico Paolo Giaccone (number 1, approved on the 17 January 2022).

Informed Consent Statement: Informed consent was obtained from all subjects involved in the study. Written informed consent has been obtained from the patient(s) to publish this paper.

Data Availability Statement: Data are available on demand at corresponding author.

Conflicts of Interest: The authors declare no conflict of interest. 


\section{References}

1. Muscogiuri, G.; Altieri, B.; Annweiler, C.; Balercia, G.; Pal, H.B.; Boucher, B.J.; Cannell, J.J.; Foresta, C.; Grübler, M.R.; Kotsa, K.; et al. Vitamin D and chronic diseases: The current state of the art. Arch. Toxicol. 2017, 91, 97-107. [CrossRef] [PubMed]

2. Marino, R.; Misra, M. Extra-skeletal effects of Vitamin D. Nutrients 2019, 11, 1460. [CrossRef] [PubMed]

3. Zendehdel, A.; Arefi, M. Molecular evidence of role of vitamin D deficiency in various extraskeletal diseases. J. Cell. Biochem. 2019, 120, 8829-8840. [CrossRef] [PubMed]

4. Bikle, D.; Christakos, S. New aspects of vitamin D metabolism and action-addressing the skin as source and target. Nat. Rev. Endocrinol. 2020, 16, 234-252. [CrossRef]

5. Pivonello, R.; Isidori, A.; De Martino, M.C.; Newell-Price, J.; Biller, B.M.K.; Colao, A. Complications of Cushing's syndrome: State of the art. Lancet Diabetes Endocrinol. 2016, 4, 611-629. [CrossRef]

6. Guarnotta, V.; Ferrigno, R.; Martino, M.; Barbot, M.; Isidori, A.M.; Scaroni, C.; Ferrante, A.; Arnaldi, G.; Pivonello, R.; Giordano, C. Glucocorticoid excess and COVID-19 disease. Rev. Endocr. Metab. Disord. 2020, 22, 703-714. [CrossRef]

7. Giordano, C.; Guarnotta, V.; Pivonello, R.; Amato, M.C.; Simeoli, C.; Ciresi, A.; Cozzolino, A.; Colao, A. Is diabetes in Cushing's syndrome only a consequence of hypercortisolism? Eur. J. Endocrinol. 2014, 170, 311-319. [CrossRef]

8. Drey, M.; Berr, C.M.; Reincke, M.; Fazel, J.; Seissler, J.; Schopohl, J.; Bidlingmaier, M.; Zopp, S.; Reisch, N.; Beuschlein, F.; et al. Cushing's syndrome: A model for sarcopenic obesity. Endocrine 2017, 57, 481-485. [CrossRef]

9. Guarnotta, V.; Prinzi, A.; Pitrone, M.; Pizzolanti, G.; Giordano, C. Circulating irisin levels as a marker of osteosarcopenic-obesity in Cushing's disease. Diabetes Metab. Syndr. Obes. 2020, 13, 1565-1574. [CrossRef]

10. Hakami, O.A.; Ahmed, S.; Karavitaki, N. Epidemiology and mortality of Cushing's syndrome. Best Pr. Res. Clin. Endocrinol. Metab. 2021, 35, 101521. [CrossRef]

11. Javanmard, P.; Duan, D.; Geer, E.B. Mortality in patients with endogenous Cushing's Syndrome. Endocrinol. Metab. Clin. North Am. 2018, 47, 313-333. [CrossRef] [PubMed]

12. McKay, L.I.; Cidlowski, J.A. Physiologic and pharmacologic effects of corticosteroids. In Holland-Frei Cancer Medicine, 6th ed.; Kufe, D.W., Pollock., R.E., Weichselbaum, R.R., Eds.; BC Decker: Hamilton, ON, Canada, 2003.

13. Tirabassi, G.; Salvio, G.; Altieri, B.; Ronchi, C.L.; Della Casa, S.; Pontecorvi, A.; Balercia, G. Adrenal disorders: Is there any role for Vitamin D? Rev. Endocr. Metab. Disord. 2016, 18, 355-362. [CrossRef] [PubMed]

14. Skversky, A.L.; Kumar, J.; Abramowitz, M.K.; Kaskel, F.J.; Melamed, M.L. Association of glucocorticoid use and low 25Hydroxyvitamin D levels: Results from the National Health and Nutrition Examination Survey (NHANES): 2001-2006. J. Clin. Endocrinol. Metab. 2011, 96, 3838-3845. [CrossRef] [PubMed]

15. Muscogiuri, G.; Altieri, B.; Penna-Martinez, M.; Badenhoop, K. Focus on Vitamin D and the Adrenal Gland. Horm. Metab. Res. 2015, 47, 239-246. [CrossRef]

16. Davidson, Z.E.; Walker, K.Z.; Truby, H. Clinical review: Do Glucocorticosteroids alter Vitamin D status? A systematic review with meta-analyses of observational studies. J. Clin. Endocrinol. Metab. 2012, 97, 738-744. [CrossRef]

17. Hidalgo, A.A.; Trump, D.L.; Johnson, C.S. Glucocorticoid regulation of the vitamin D receptor. J. Steroid Biochem. Mol. Biol. 2010, 121, 372-375. [CrossRef]

18. Hidalgo, A.A.; Deeb, K.K.; Pike, J.W.; Johnson, C.S.; Trump, D.L. Dexamethasone enhances $1 \alpha, 25$-Dihydroxyvitamin D3 effects by increasing Vitamin D receptor transcription. J. Biol. Chem. 2011, 286, 36228-36237. [CrossRef]

19. Favus, M.J.; Kimberg, D.V.; Millar, G.N.; Gershon, E. Effects of cortisone administration on the metabolism and localization of 25-Hydroxycholecalciferol in the rat. J. Clin. Investig. 1973, 52, 1328-1335. [CrossRef]

20. Kugai, N.; Koide, Y.; Yamashita, K.; Shimauchi, T.; Nagata, N.; Takatani, O. Impaired mineral metabolism in Cushing's syndrome: Parathyroid function, vitamin D metabolites and osteopenia. Endocrinol. Jpn. 1986, 33, 345-352. [CrossRef]

21. Aloia, J.F.; Roginsky, M.; Ellis, K.; Shukla, K.; Cohn, S. Skeletal metabolism and body composition in Cushing's Syndrome. J. Clin. Endocrinol. Metab. 1974, 39, 981-985. [CrossRef]

22. Findling, J.W.; Adams, N.D.; Lemann, J., Jr.; Gray, R.W.; Thomas, C.J.; Tyrrell, J.B. Vitamin D metabolites and parathyroid hormone in Cushing's Syndrome: Relationship to calcium and phosphorus homeostasis. J. Clin. Endocrinol. Metab. 1982, 54, 1039-1044. [CrossRef] [PubMed]

23. Seeman, E.; Kumar, R.; Hunder, G.G.; Scott, M.; Heath, H., 3rd; Riggs, B.L. Production, degradation, and circulating levels of 1,25-dihydroxyvitamin D in health and in chronic glucocorticoid excess. J. Clin. Investig. 1980, 66, 664-669. [CrossRef] [PubMed]

24. Klein, R.G.; Arnaud, S.B.; Gallagher, J.C.; DeLuca, H.F.; Riggs, B.L. Intestinal calcium absorption in exogenous Hypercortisonism. J. Clin. Investig. 1977, 60, 253-259. [CrossRef] [PubMed]

25. Chaiamnuay, S.; Chailurkit, L.-O.; Narongroeknawin, P.; Asavatanabodee, P.; Laohajaroensombat, S.; Chaiamnuay, P. Current daily glucocorticoid use and serum creatinine levels are associated with lower $25(\mathrm{OH})$ Vitamin D levels in Thai patients with systemic lupus erythematosus. JCR J. Clin. Rheumatol. 2013, 19, 121-125. [CrossRef]

26. Slovik, D.M.; Neer, R.M.; Ohman, J.L.; Lowell, F.C.; Clark, M.B.; Segre, G.V.; Potts, J.T., Jr. Parathyroid hormone and 25hydroxyvitamin D levels in glucocorticoid-treated patients. Clin. Endocrinol. 1980, 12, 243-248. [CrossRef]

27. Lindgren, J.U.; Merchant, C.R.; DeLuca, H.F. Effect of 1,25-dihydroxyvitamin D3 on osteopenia induced by prednisolone in adult rats. Calcif. Tissue Res. 1982, 34, 253-257. [CrossRef]

28. Corbee, R.; Tryfonidou, M.; Meij, B.; Kooistra, H.; Hazewinkel, H. Vitamin D status before and after hypophysectomy in dogs with pituitary-dependent hypercortisolism. Domest. Anim. Endocrinol. 2012, 42, 43-49. [CrossRef] 
29. Park, J.E.; Pichiah, P.T.; Cha, Y.-S. Vitamin D and metabolic diseases: Growing roles of Vitamin D. J. Obes. Metab. Syndr. 2018, 27, 223-232. [CrossRef]

30. Medrano, M.; Carrillo-Cruz, E.; Montero, I.; Perez-Simon, J.A. Vitamin D: Effect on Haematopoiesis and immune system and clinical applications. Int. J. Mol. Sci. 2018, 19, 2663. [CrossRef]

31. Fleseriu, M.; Auchus, R.; Bancos, I.; Ben-Shlomo, A.; Bertherat, J.; Biermasz, N.R.; Boguszewski, C.L.; Bronstein, M.D.; Buchfelder, M.; Carmichael, J.D.; et al. Consensus on diagnosis and management of Cushing's disease: A guideline update. Lancet Diabetes Endocrinol. 2021, 9, 847-875. [CrossRef]

32. Nieman, L.K.; Biller, B.M.K.; Findling, J.W.; Newell-Price, J.; Savage, M.O.; Stewart, P.M.; Montori, V. The diagnosis of Cushing's Syndrome: An endocrine society clinical practice guideline. J. Clin. Endocrinol. Metab. 2008, 93, 1526-1540. [CrossRef] [PubMed]

33. Expert Panel on Detection, Evaluation, Treatment of High Blood Cholesterol in Adults. Executive summary of the third report of the National Cholesterol Education Program (NCEP) expert panel on detection, evaluation, and treatment of high blood cholesterol in adults (Adult Treatment Panel III). JAMA 2001, 285, 2486-2497. [CrossRef] [PubMed]

34. American Diabetes Association. Classification and diagnosis of diabetes: Standards of medical care in diabetes-2021. Diabetes Care 2021, 44 (Suppl. S1), S15-S33. [CrossRef] [PubMed]

35. Guarnotta, V.; Amato, M.C.; Pivonello, R.; Arnaldi, G.; Ciresi, A.; Trementino, L.; Citarrella, R.; Iacuaniello, D.; Michetti, G.; Simeoli, C.; et al. The degree of urinary hypercortisolism is not correlated with the severity of cushing's syndrome. Endocrine 2016, 55, 564-572. [CrossRef] [PubMed]

36. Holick, M.F.; Binkley, N.C.; Bischoff-Ferrari, H.A.; Gordon, C.M.; Hanley, D.A.; Heaney, R.P.; Murad, M.H.; Weaver, C.M. Endocrine Society. Evaluation, treatment, and prevention of Vitamin D deficiency: An endocrine society clinical practice guideline. J. Clin. Endocrinol. Metab. 2011, 96, 1911-1930. [CrossRef]

37. Fiebrich, H.-B.; Berg, G.V.D.; Kema, I.P.; Links, T.P.; Kleibeuker, J.H.; Van Beek, A.P.; Walenkamp, A.M.E.; Sluiter, W.J.; De Vries, E.G.E. Deficiencies in fat-soluble vitamins in long-term users of somatostatin analogue. Aliment. Pharmacol. Ther. 2010, 32, 1398-1404. [CrossRef]

38. Matthews, D.R.; Hosker, J.P.; Rudenski, A.S.; Naylor, B.A.; Treacher, D.F.; Turner, R.C. Homeostasis model assessment: Insulin resistance and $\beta$-cell function from fasting plasma glucose and insulin concentrations in man. Diabetologia 1985, 28, 412-419. [CrossRef]

39. Matsuda, M.; DeFronzo, R.A. Insulin sensitivity indices obtained from oral glucose tolerance testing: Comparison with the euglycemic insulin clamp. Diabetes Care 1999, 22, 1462-1470. [CrossRef]

40. Utzschneider, K.M.; Prigeon, R.L.; Faulenbach, M.V.; Tong, J.; Carr, D.B.; Boyko, E.J.; Leonetti, D.L.; McNeely, M.J.; Fujimoto, W.Y.; Kahn, S.E. Oral disposition index predicts the development of future diabetes above and beyond fasting and 2-h glucose levels. Diabetes Care 2009, 32, 335-341. [CrossRef]

41. Glendenning, P.; Zhu, K.; Inderjeeth, C.; Howat, P.; Lewis, J.R.; Prince, R.L. Effects of three-monthly oral 150,000 IU cholecalciferol supplementation on falls, mobility, and muscle strength in older postmenopausal women: A randomized controlled trial. J. Bone Miner. Res. 2011, 27, 170-176. [CrossRef]

42. Kearns, M.D.; Alvarez, J.A.; Tangpricha, V. Large, single-dose, oral Vitamin D supplementation in adult populations: A systematic review. Endocr. Pract. 2014, 20, 341-351. [CrossRef] [PubMed]

43. Lundqvist, J.; Norlin, M.; Wikvall, K. 1 1 ,25-Dihydroxyvitamin D3 affects hormone production and expression of steroidogenic enzymes in human adrenocortical NCI-H295R cells. Biochim. Biophys. Acta 2010, 1801, 1056-1062. [CrossRef] [PubMed]

44. Lemieux, P.; Weisnagel, S.J.; Caron, A.Z.; Julien, A.-S.; Morisset, A.-S.; Carreau, A.-M.; Poirier, J.; Tchernof, A.; Robitaille, J.; Bergeron, J.; et al. Effects of 6-month vitamin D supplementation on insulin sensitivity and secretion: A randomised, placebo-controlled trial. Eur. J. Endocrinol. 2019, 181, 287-299. [CrossRef] [PubMed]

45. Li, Y.; Tong, C.H.; Rowland, C.M.; Radcliff, J.; Bare, L.A.; McPhaul, M.J.; Devlin, J.J. Association of changes in lipid levels with changes in vitamin D levels in a real-world setting. Sci. Rep. 2021, 11, 21536. [CrossRef] [PubMed]

46. Dibaba, D.T. Effect of vitamin D supplementation on serum lipid profiles: A systematic review and meta-analysis. Nutr. Rev. 2019, 77, 890-902. [CrossRef] [PubMed]

47. Povaliaeva, A.; Bogdanov, V.; Pigarova, E.; Zhukov, A.; Dzeranova, L.; Belaya, Z.; Rozhinskaya, L.; Mel'Nichenko, G.; Mokrysheva, $\mathrm{N}$. Assessment of Vitamin D metabolism in patients with Cushing's disease in response to 150,000 IU cholecalciferol treatment. Nutrients 2021, 13, 4329. [CrossRef] 